\title{
KONSEP MAKRIFAT MENURUT AL-GHAZALI DAN IBNU 'ARABI: SOLUSI ANTISIPATIF RADIKALISME KEAGAMAAN BERBASIS EPISTEMOLOGI
}

\author{
A. Zaini Dahlan \\ Fakultas Syariah Institut Perguruan Tinggi Ilmu Al-Quran Jakarta \\ Email: azaidah53@yahoo.co.id \\ Siti Chamamah Soeratno dan Sangidu \\ Fakultas Ilmu Budaya Universitas Gadjah Mada \\ Ahmad Mursyidi \\ Fakultas Farmasi Universitas Gadjah Mada
}

\begin{abstract}
Al-Ghazali (1058-1111) is Sunni sufi representing Islamic mysticism and Ibnu Arabi (1165-1240) represents philosophical Sufism. Al- Ghazali's concept of Gnosis (knowing God) is based on the Quran and Hadith which is similar to its predecessor, al asy'ari. In contrast, Ibnu Arabi's concept of Gnosis is based on Greek philosophy and the school of Bathiniyah (Syiah). The fundamental difference between the two scholars is that Al-Ghazali is consistent with classical model of epistemological interpretation. He is very cautious in preventing understanding Islam (the sunni view) especially on aqidah (faith) from polytheism (musyrik) or infidelity (kafir). Meanwhile, Ibnu Arabi explores a variety of sources: Greek philosophy, school of shi'i Bathiniyah, and other sources with contempory interpretation paradigms whose characteristics are pluralistic, multicultural and universal, and gives more priority to welfare and justice. Even though the paradigm used by Al-Ghazali differs from the one employed by Ibnu Arabi, they agree in some points. There are similarities in their paradigms and understandings. Al- Ghazali even justifies the righteousness of paradigm deployed by Ibnu arabi. Reflections of the two scholars' paradigms bear the main principles of mysticism. Al-Ghazali develops it with tahalli, takhalli, and tajalli, while Ibnu Arabi in addition to the three of Al Ghazali develops it with the teaching of wahdatul wujud.
\end{abstract}

Keywords: Gnosis, solution, antisipative, radicalism, epistemolgy

\begin{abstract}
ABSTRAK
Al Ghazali (1058-1111) merupakan representasi tasawuf sunni, sementara Ibnu Arabi (1165-1240) representasi tasawuf falsafi. Al-Ghazali dalam konsepnya tentang makrifat (mengenal tuhan) lebih kental berbasis pada teks suci (Al qur'an dan Hadits) -sebagaimana paham pendahulunya, al Asy'ari. Sebaliknya Ibnu Arabi berbasis pada- filsafat Yunani dan ajaran madzhab Bathiniyah (Syiah). Perbedaan mendasar dari dua tokoh tersebut adalah al Ghazali masih konsisten dengan epistemologi penafsiran model klasik yang amat hati-hati dalam memahami ajaran islam khususnya akidah (keyakinan) sehingga seseorang terhindar dari vonis sebagai orang musyrik atau kafir dalam pandangan Sunni. Sementara Ibnu Arabi dengan dibekali berbagai pemikiran filsafat Yunani, aliran Bathiniyah, dan ajaran
\end{abstract}




\section{A. Zaini Dahlan -- Konsep Makrifat Menurut Al-Ghazali dan Ibnu 'Arabi: Solusi Antisipatif Radikalisme Keagamaan Berbasis Epistemologi}

agama lainnya, dia membangun paradigma penafsiran kontemporer yang indikatornya bersifat pluralis, multikultural, universal serta lebih mengutamakan kemaslahatan dan keadilan. Meskipun paradigma yang dibangun al ghazali berbeda dengan Ibnu 'Arabi, tetapi ada titik temu di antara keduanya, bahkan Al Ghazali dinilai menjustifikasi kebenaran paradigma yang dibangun oleh Ibnu 'Arabi. Refleksi dari paradigma dua tokoh tersebut melahirkan "nodes" (prinsip-prinsip utama) dalam tasawuf. Al-Ghazali mencanangkannya dengan tahalli, takhalli dan tajalli. Sementara Ibnu Arabi, disamping tiga serangkai di atas, membangunnya dengan ajaran wahdatul wujud.

Kata kunci: Makrifat, solusi, antisipatif, radikalisme, epistemologi.

\section{PENGANTAR}

Radikalisme dalam praktek keberagamaan umat islam, khususnya dalam bidang tasawuf nampaknya, merupakan catatan sejarah yang tidak mungkin terlupakan. Sebagai contoh, Dzunun al Misri $($ w.860 M) sebagai pelopor paham makrifat dihukum mati oleh ahli hukum madzhab Maliki Abdullah ibn Abdul Hakam (Azra, 2002: 121) karena ajaran makrifatnya. Nasib yang sama dikenakan kepada Husein ibn Mansur al-Hallaj (858-922 M) karena paham hululnya. Sufi yang lainnya seperti Ibn alQasi dibunuh pada tahun 1151 M, juga Ibn Barrajan dan Ibn al-Arif yang konon diracun oleh gubernur Afrika Utara Ali ibn Yusuf (Azhari, 1995: 20). Memang para peneliti ada yang mengaitkan pembunuhan tersebut dengan alasan politik, sementara yang lainnya memberi alasan karena paham atau ajaran yang dibangunnya (Azra, 2002 : 121).

Mengacu kepada alasan kedua, W. Montgomery Watt mengungkapkannya sebagai tradisi klasik yang tetap hidup subur dalam sejarah Islam sampai sekarang. Ia mengistilahkannya sebagai "heresiographycal tradition" (Watt, 1972: 1) sebagai pandangan yang menganggap bid'ah (tidak otentik) dan sesat suatu aliran, madzhab, atau kelompok keagamaan lain dalam Islam. Konsekuensi dari pandangan ini adalah hanya aliran, madzhab atau kelompok keagamaannya sendiri yang benar danmengikutijalanyanglurus. Padahal kalau melihat sejarah dibangunnya agama Islam oleh Nabi Muhammad seperti tercantum dalam piagam Madinah, fenomenanya amat jauh dari sikap dan aksi radikalisme di atas.

Piagam Madinah yang berisi 47 pasal itu memuat prinsip dasar yang menjadi landasan bagi kehidupan demokrasi untuk segala masa dan tempat, yaitu (1) prinsip kesatuan umat, bangsa, dan komunitas; (2) Kolektivitas dan solidaritas sosial; (3) perlindungan dan pembelaan terhadap yang lemah dan tertindas; (4) keadilan sosial; (5) perdamaian antara sesama dan lingkungan; (6) persamaan di depan hukum; (7) kebebasan berpendapat, berorganisai, berekspresi dan beragama; (8) menjunjung tinggi HAM; (9) nasionalisme; (10) equalitas sosial; dan (11) musyawarah (Wahid, 2005: 104).

Membandingkan "kasus hukum mati" sebagai akibat dengan tradisi heresiografi yang hidup di kalangan umat Islam khususnya sebagai penyebab yang kemudian melahirkan konflik-konflik yang terjadi antar sesama umat beragama atau bahkan pembunuhan antar sesama umat Islam. Akar masalahnya berada pada pernyataanpernyataan yang mengatas namakan ajaran agama. Lebih jelasnya, konflik-konflik itu diidentifikasi muncul berkaitan dengan masalah hubungan manusia dengan Tuhan, yaitu pengenalannya dengan Tuhan (makrifat). Dengan demikian masalah yang akan dibahas adalah bagaimana konsep makrifat menurut Al-Ghazali dan konsep makrifat menurut Ibnu 'Arabi.

Kata "makrifat" berasal dari bahasa arab 'arafa-ya'rifu-'irfan-ma' rifah (kata benda) yang berarti pengetahuan atau pengenalan (Ali, tt: 183) yang berarti pengetahuan tentang rahasia hakikat agama, yaitu ilmu yang lebih tinggi dari pada ilmu yang biasa didapati oleh orang-orang pada umumnya (Saliba, 1979: 72). Makrifat sebagai suatu ajaran atau paham dalam disiplin tasawuf dikaji dalam dua fersi dengan alirannya masing-masing, yaitu tasawuf sunni/amali dan tasawuf falsafi. 
Membandingkan buku-buku tasawuf karya al-Ghazali (al-Ihya dan al-Munqidz) yang diidentifikasi sebagai aliran tasawuf Sunni/akhlaqi dan beraliran Ahlus Sunnah dengan buku-buku tasawuf Ibnu Arabi (alFutuhat dan al Fushush) yang diidentifikasi sebagai aliran tasawuf falsafi dan beraliran Syi'ah (al-Dzahabi, tt: 659) ini sejatinya bertujuan mengungkapkan tanggapan pembaca yaitu al- Ghazali dan Ibnu 'Arabi yang membaca teks suci (Al qur'an dan Sunnah) kemudian melahirkan konsep makrifat yang terkandung dalam buku-buku mereka tersebut dalam kaitan perbedaan persepsi tentang makrifat. Karena itu, kajian dalam masalah ini mempunyai dua tujuan, yaitu tujuan teoritis dan tujuan praktis.

Tujuan teoritisnya adalah menganalisis dan mengkritisi konsep makrifat dari kedua tokoh tersebut kemudian menyimpulkannya dengan berpedoman kepada teori dan paradigma ilmu pengetahuan kontemporer yang bernuansa kekinian sehingga menghasilkan sebuah ajaran yang bersifat inklusifistik, pluralistik, dan multi kultural dengan mengutamakan prinsip kemanfaatan dan kemashlahatan serta tidak melanggar aturan Syara' (agama). Dari hasil analisis itu, kemudian ada satu rumusan pemahaman komprehensif yang dapat dijadikan solusi dan sekaligus sebagai rujukan bagi para peminat kajian tasawuf. Sementara tujuan praktisnya adalah mengungkapkan konsep makrifat yang terdapat dalam kitab masing-masing kedua tokoh tersebut dan mengungkapkan sumber-sumber ajaran makrifat mereka, serta memahaminya dari segi ontologi, epistemologi, dan axiologi.

Dengan keberhasilan meneliti sumber ajaran makrifat mereka dari segi ontologi, epistemologi dan axiologi kemudian dilanjutkan dengan menjelaskan kerangka berpikir munculnya konsep ajaran makrifat tersebut sebagai langkah antisipatif munculnya pro dan kontra di masyarakat, maka dapat diharapkan ada pemahaman baru tentang makrifat sehingga ilmu tasawuf bermanfaat baik bagi masyarakat awam pada umumnya maupun masyarakat terpelajar.
Hal ini menunjukan ada peningkatan kesadaran dalam aktivitas keberagamaan di masyarakat dan sekaligus sebagai bukti sejarah bahwa ada perkembangan pemikiran tentang tasawuf di masyarakat Islam. Selain itu, pada langkah selanjutnya, dengan adanya pemahaman baru dalam ilmu tasawuf diharapkan tidak ada lagi polemik antara golongan Syari'at (ahli fikih) dengan golongan Hakikat (ahli tasawuf) dan begitu juga dengan golongan Mutakallimin (ahli kalam). Di samping itu, -dan ini yang lebih penting- kecaman dan bahkan memvonis "kafir" terhadap aliran tasawuf diharapkan tidak akan ada lagi. Munculnya kecaman terhadap aliran-aliran yang dinilai sesatpun akan teredam dengan sendirinya.

\section{PEMBAHASAN}

Kajian tantang makrifat secara khusus pernah ditulis oleh Muhamad Ghallab

dengan judul "Makrifat Menurut Ibnu Arabi" (al Makrifah 'ind Ibn Arabi) diterbitkan oleh Hayat misriyah 'Ammah li atta'lif wa annasr, juga buku konsep makrifat menurut Al qur'an dan filsafat (Nadzhariyat al Makrifat Bain Al qur'an wa al Falsafah) karya Rajih Abd Hamid al Kurdi, dengan penerbit Dar al Furqan li annasr wa al Tauzi', Yordania. Membicarakan karyakarya yang membahas tentang Ibnu Arabi memang telah banyak ditulis. Azhari (1995) diantaranya menulis Ibn al-Arabi: Wahdat al-Wujud dalam Perdebatan dan H.S. Nyberg dengan karyanya Kleinere Schriften des Ibn Arabi. Karya ini memberikan penilaian kritis terhadap beberapa pandangan metafisis Ibnu 'Arabi.

M. Asin Palacios yang menulis buku El Islam cristianizado yang berisi uraian lengkap dan rinci tentang kehidupan Ibnu 'Arabi dan meringkas tentang pemikiran mistikoetisnya. Dalam komentar Masataka Takeshita, kedua sarjana tersebut berusaha memahami asal-usul pemikiran Ibnu Arabi dalam berbagai tradisi pra-Islam dan Islam. Anehnya, komentar selanjutnya, kedua sarjana ini sama sekali tidak merujuk kepada karya Ibnu Arabi yang paling matang yaitu 


\section{A. Zaini Dahlan -- Konsep Makrifat Menurut Al-Ghazali dan Ibnu 'Arabi: Solusi Antisipatif Radikalisme Keagamaan Berbasis Epistemologi}

Fushushul Hikam. Sementara Nyberg sedikit sekali menggunakan al-futuhat al-makkiyyah sebagai karya terbesar Ibnu Arabi.

Karya Abul A'la Afifi The Mistical Philosophy of Muhyiddin Ibnul Arabi sangat berharga untuk mempelajari pemikiran Ibnu Arabi. Dalam karyanya itu, A. E. Afifi memberikan penyajian sistematis pandangan mistik Ibnu Arabi. Komentar M. Takashita tentang karya ini mengungkapkan bahwa studi perbandingan mengenai Ibnu Arabi dan pemikir-pemikir pra-Islam dan Islam yang dilakukannya terlalu sederhana dan dangkal (Azhari, 1995: 9).

Rom Landau dalam karyanya The Philosophy of Ibn 'Arabi memberi informasi yang berguna untuk mempelajari aspekaspek pemikiran Ibnu Arabi yang berupa kutipan dari karya-karya Ibnu Arabi, namun tidak memberikan analisis yang kritis dan mendalam. Seyyed Hossein Nasr juga menulis tentang Ibnu Arabi dalam bagian ketiga karyanya Three Muslim Sages. Meskipun tulisan itu pendek tapi bermanfaat untuk mempelajari pemikiran Ibnu Arabi. Karya-karya lain yang berupa perbandingan adalah Sufism and Taoism karya Toshihiko Izutsu. Karya ini membandingkan Ibnu Arabi, Lao-tzu dan Chuang-tzu melalui analisis semantik secara metodologis tentang istilah-istilah kunci ketiga pemikir tersebut. Kelebihan karya ini terletak pada kedalaman interpretasinya tentang istilah-istilah kunci dan kaitannya satu sama lain. Meski karya ini ada kelemahannya yang hanya bertumpu pada satu karya Ibnu Arabi yaitu Fushush alHikam dengan bantuan komentar Al-Qasyani tentang buku tersebut (Azhari, 1995: 9).

Studi perbandingan yang kritis antara teori-teori emanasi plotinus, Jhon the Scott, Meister Eckhart, dan Ibnu 'Arabi telah dilakukan oleh Michael Anthony Sells dalam karyanya "The Metaphor and Dialectic of Emanation in Plotinus, Jhon the Scot, and Ibn Arabi." Karya ini membicarakan Ibnu Arabi tentang tajalli (penampakan diri Tuhan) atau Fayd (emanasi) dan membandingkannya dengan pendapat ketiga tokoh di atas tentang masalah yang sama. Karya lainnya adalah
Falsafatal-Ta'wilDirasah fiTa'wilal-Qur'an inda Muhyi al-Din Ibn Arabi yang ditulis oleh Nasr Hamid Abu Zayd. Karya ini menbicarakan filsafat Ibnu Arabi yang berkenaan dengan segi-segi ontologis dan epistemologis yang didukung dengan pena'wilan ayat-ayat alQur'an.

Karya yang berjudul Ibn Al-Arabi Wahdat al-Wujud dalam Perdebatan yang ditulis oleh Kautsar Azhari Noer juga membicarakan tentang pemikiran Ibnu Arabi, yaitu membicarakan wahdatul wujud sebagai doktrin metafisis sufisme Ibnu Arabi. Doktrin itu menolak ajaran pantheisme yang menyatakan bahwa segala sesuatu berasal dari satu yang bersifat materialistik dan berbeda dengan ajaran wahdatul wujud. Dari karya-karya ilmiah yang membicarakan tentang Ibnu Arabi tersebut, tidak ada yang secara khusus membahas tentang makrifat, begitupun dari karya-karya tentang alGhazali. Dengan demikian, penelitian yang akan dilakukan merupakan penelitian yang original dan inputnya akan memberi wawasan tentang konsep makrifat yang bernuansa kekinian.

\section{Ajaran Makrifat}

Ajaran makrifat secara teoritis tekstualis berawal dari penafsiran ayat QS al-Dzariyat: 56 yang artinya "dan aku tidak menciptakan jin dan manusia melainkan supaya mereka mengabdi kepada-Ku." Kalimat "supaya mereka mengabdi kepada-Ku" menurut Ibnu Abbas berarti "agar mereka mengenal-Ku (Allah), yaitu makrifat. Sementara pada QS. al-An' am: 91 yang artinya "dan mereka tidak menghormati Allah dengan penghormatan yang semestinya" (Al-Kusairi, 2007: 168).

Ada sebagian tafsir yang menuliskan bahwa ayat itu berarti "mereka tidak mengenal (makrifat) Allah sebagaiman seharusnya Ia dikenal" (Al-Thusi, 2001:38). Sumber lain ajaran makrifat adalah dua buah hadits Qudsi dari Abi Hurairah yang diriwayatkan al-Bukhari yang artinya: “..... dan hamba-Ku senantiasa berusaha mendekatkan diri kepada-Ku dengan amalan-amalan sunnah sehingga Aku mencintainya. Jika Aku telah mencintainya, 
maka Aku menjadi (alat) pendengarannya yang ia mendengar, dengan alat itu menjadi (alat) penglihatannya yang ia melihat dengan alat itu, menjadi tangannya yang dengannya ia memukul, dan kakinya yang dengannya ia berjalan" (Al-Bukhari, ttp: III, 131) dan sebuah hadis yang bermakna "Barangsiapa mendekatiKu satu meter maka Aku akan mendekatinya sehasta. Dan barangsiapa mendekati-Ku sehasta maka Aku akan mendekatinya sedepa" (al-Jili, tt: 8), serta hadits lain yang artinya "Pada mulanya Aku merupakan misteri yang tersimpan dan belum dikenal kemudian Aku rindu ingin dikenal lalu Aku ciptakan makhluk dan Aku berkenalan dengan mereka, akhirnya merekapun mengenalku" (Ibnu 'Arabi, t.t: II, 399).

Sementara ajaran makrifat secara praktis bersumber dari teks Al qur'an dan sunnah seperti -kisah Umar ibn al-Khattab ketika sedang berkhutbah shalat Jumat tiba-tiba ia memerintahkan pasukan perangnya untuk bertahan di tempat pada satu peperangan, kisah sahabat Nabi Sulaiman, Asif, (QS. anNaml: 40) dan kisah tentang Nabi Khidir dan Nabi Musa (QS.al-Kahfi: 71-83). Dari dua sumber di atas kemudian muncul berbagai penafsiran yang kemudian melahirkan beberapa konsep makrifat yang berbeda dari beberapa tokoh sufi seperti al-Busthami, alHallaj, al-Ghazali dan Ibn Arabi.

Munculnya berbagai penafsiran merupakan refleksi dari perbedaan pengalaman, pengetahuan dan lingkungan dimana pembaca teks berada yang kemudian melahirkan tanggapan pembaca. Penelitian tentang konsep makrifat ini merupakan penelitian budaya, sebab dalam penelitian ini mengungkap tanggapan pembaca atas pembacaan suatu teks. Jadi realnya adalah meneliti ungkapan atau pendapat satu atau beberapa orang sebagai pembaca umum yang menanggapi atau merespon atas hasil pembacaan suatu teks. Dengan demikian, dalam penelitian ini akan dimanfaatkan teori resepsi. Berikut ini akan dikemukakan dasardasar teori resepsi dan metodenya.

Teori resepsi berasal dari kata receive yang berarti menerima (Echols dan Shadily,
1987: 469). Teori ini merupakan suatu disiplin yang memandang penting peran pembaca dalam memberikan makna suatu teks (Jauss dalam Sangidu, 2005: 20). Sebagaimana diketahui bahwa pembaca merupakan faktor penting dalam memberikan interpretasi tentang suatu karya karena peneliti lebih banyak bekerja dengan teks yang diteliti (Jauss, 1985: 27).

Berbicara tentang resepsi atau cara seorang pembaca menerima dan memahami suatu teks dapat merujuk teori Iser. Ia mengatakan bahwa sebuah teks dapat didefinisikan sebagai wilayah indeterminasi atau wilayah ketidakpastian (indeterminacy areas) (Iser dan Segers dalam Sangidu, 2005: 21). Wilayah ketidakpastian merupakan "bagian-bagian kosong" atau "tempattempat terbuka" (leerstellen, open plek) yang "mengharuskan" pembaca untuk mengisinya. Hal ini disebabkan oleh sifat karya yang mempunyai banyak tafsir (polyinterpretability) (Pradopo, 1995: 235).

Dalam mengisi "tempat-tempat kosong", pembaca dapat mengacu pada bahan yang diangkat dari répertoire-nya (bekal atau bahan yang berupa pengetahuan dan pengalaman pembaca) sehingga lahirlah realisasi teks (Iser dalam Sangidu, 2005: 21). Realisasi teks berupa resepsi (tanggapan) dan penafsiran yang berbeda-beda dari para pembaca karena mereka telah dibekali oleh pengalaman dan pengetahuan yang berbedabeda pula. Karena itu, ada kemungkinan satu karya memperoleh makna yang bermacammacam dari berbagai kelompok pembaca (Soeratno dalam Sangidu, 2005 : 21). Hal itu justru menunjukkan adanya struktur teks yang dinamis, makna karya akan selalu diperkaya dan dapat lebih terungkap, serta nilai sastranya pun dapat ditentukan lebih baik (Pradopo, 1995 : 234).

Faktor pembaca, dalam poros komunikasi mendapat pengertian yang bermacam-macam. Salah satu di antaranya yang akan dimanfaatkan di dalam penelitian yang berkaitan dengan dua kitab monumental karya al-Ghazali yaitu al Ihya dan al-Munqidz dan dari karya Ibnu Arabi 


\section{A. Zaini Dahlan -- Konsep Makrifat Menurut Al-Ghazali dan Ibnu 'Arabi: Solusi Antisipatif Radikalisme Keagamaan Berbasis Epistemologi}

yaitu kitab al-Futuhat dan al- Fushush ini adalah pembaca nyata (real reader). Pembaca ini merupakan pembaca dalam arti fisik, yaitu manusia yang melaksanakan tindakan pembacaan. Pembaca dalam konteks ini meliputi pembaca peneliti dan pembaca umum. Pembaca umum dalam resepsinya berupa reaksi atau tanggapan terhadap sebuah teks seperti yang dipahaminya dan ia berdiri di dalam proses pembacaan.

Sementara itu, pembaca peneliti dalam resepsinya berupa reaksi atau tanggapan terhadap pembaca umum yang telah meresepsi sebuah teks dan ia berdiri di luar proses pembacaan. Dalam penelitian terhadap kitab karya Al-Ghazali dan Ibnu Arabi ini, pembaca yang dimaksudkan adalah pembaca umum yaitu al Ghazali dan Ibnu Arabi. Tanggapan terhadap suatu karya sastra dari seorang pembaca ke pembaca yang lain dan dari satu periode ke periode yang lain selalu berbeda-beda disebabkan oleh horizon harapannya (Jauss dalam Sangidu , 2005 : 20 ).

Horizon harapan yang berbeda-beda antara satu pembaca dan pembaca yang lain, dalam satu periode ke periode yang lain ditentukan oleh tiga kriteria (Segers dalam Sangidu, 2005: 21). Tiga kriteria tersebut adalah (1) norma norma yang terpencar dari teks-teks yang telah dibaca oleh pembaca; (2) pengalaman dan pengetahuan pembaca atas semua teks yang telah dibaca sebelumnya; dan (3) pertentangan antara fiksi dengan kenyataan, yaitu kemampuan pembaca untuk memahami teks baru, baik dalam horizon yang sempit dari harapan-harapan sastra maupun dalam horizon luas yang bersumber pada pengetahuan pembaca tentang kehidupan (Pradopo, 1955: 234).

Dari pembicaraan teori resepsi di atas, penelitian terhadap kitab monumental karya al-Ghazali dan dari karya Ibnu Arabi ini dilakukan lewat metode kritik teks dan intertekstual. Untuk mengaplikasikan metode kritik teks dan intertekstual tersebut maka uraiannya sebagai berikut. Ajaran makrifat bersumber dari penafsiran atau resepsi dari pembacaan terhadap teks suci yaitu ayat 56 surat al-Dzariyat : "Aku menciptakan jin dan manusia hanya agar mereka beribadat kepada $\mathrm{Ku}^{\prime \prime}$ yang ditafsiri oleh Ibnu Abbas dan al-Jaelani (al-Jaelani, 2009: 5, 425) dan Ibnu Arabi (t.t: 2, 575) dengan makrifat. Pendapat ini diperkuat dengan hadits Qudsi (Nasution, 1973: 61) yang bermakna "Aku pada mulanya adalah simpanan yang tersembunyi, kemudian Aku ingin dikenal, maka Kuciptakan makhluk lalu merekapun mengenal-Ku" (al- Kusairi, 2004: 168).

Dari dua teks suci tersebut kemudian muncullah berbagai penafsiran tentang arti makrifat seperti dikemukakan oleh al Bustami, al Hallaj, al Ghazali dan Ibnu Arabi. Penafsiran al Ghazali tentang makrifat sebagai "terbukanya rahasia-rahasia ketuhanan dan tersingkapnya aturan-aturan Tuhan yang meliputi segala yang ada" (al-Ghazali, 3: 400) mengindikasikan orientasi perdebatan teologis pada masa itu didominasi oleh perdebatan tentang ketuhanan sehingga berpengaruh kepada pemikiran al Ghazali tentang konsep makrifatnya (Mitsa, 2005: 24). Konsep Ibnu Arabi tentang makrifat yang menyatakan bahwa tuhan adalah realitas dari segala sesuatu yang ada di alam ini (Ibnu Arabi, tt: 604). Ia sangat dipengaruhi oleh pemikiran filsafat al Hallaj termasuk bagian dari tasawuf falsafi seperti Abu Yazid al-Busthami sehingga paradigma yang dibangunnya pun seperti yang dibangun oleh al-Hallaj. Pada sisi filosofis, ia lebih mirip seorang Neoplatonis, sementara pada sisi mistis, gayanya sama seperti al Hallaj, tapi tidak dalam kekuatan emosionalnya (Afifi, 2009: 291).

\section{Konsep Tentang Kebenaran}

Dalam agama terkandung normanorma dan etika, seperti baik dan buruk, benar dan salah, dan lain-lain. Mengenai konsep kebenaran orang merasa sulit untuk mendefinisikannya. Karena kebenaran berkaitan dengan keyakinan, sedangkan keyakinan sulit untuk bisa dipercayai semua orang. Jadi orang bisa berbeda pendapat dalam mendefinisikannya. Ada yang mengatakan bahwa kebenaran adalah kesesuaian antara konsep dengan realitas, kesesuaian antara 
sesuatu yang diyakini dan kenyataan di lapangan. Hal ini sulit didapati dalam agama karena apa yang diyakini seringkali tidak bisa ditunjukkan dalam realitas di lapangan. Kebenaran memang berasal dari wilayah subyektivitas, tetapi subyektifitas bukan berarti tidak mengandung sesuatu yang benar. Misalnya seperti sebuah konsep dalam Al qur'an (QS. at-Thalaq: 2) menyatakan barang siapa bertaqwa kepada Allah, maka Allah akan memberi solusi persoalan hidupnya. Konsep ini bisa benar, namun benar di sini pengertiannya bukan benar sebagaimana dalam ilmu matematika. Bisa jadi seseorang sudah bertaqwa, tetapi persoalan yang dihadapinya belum terselesaikan (Mahasin, 2003: 140)

Ada kesulitan bagi para tokoh agama dalam melakukan tradisi akademik untuk meletakkan Islam sebagai subyek studi ilmiah. Dalam hal ini, Waardenburg menjelaskan bahwa kesulitan menjadikan agama sebagai lahan kajian ilmiah bersumber dari dua hal, yaitu:

Pertama, mengkaji berarti melakukan obyektivasi atau merasa ada jarak antara pengkaji dengan obyek kajiannya. Dalam kajian terhadap agama, obyektivasi itu dilakukan bukan kepada pihak lain melainkan juga kepada dirinya sendiri. Hal ini bukan persoalan yang mudah karena setiap manusia akan memiliki keterlibatan dengan aspek keagamaannya.

Kedua, secara tradisional, agama dipahami oleh para pemeluknya sebagai sesuatu yang suci, sakral, dan agung. Padahal, menempatkan sesuatu yang memiliki nilai tinggi sebagai obyek netral, akan dianggap mereduksi, melecehkan, bahkan merusak nilai tradisional keagamaan (Waardenburg, 1973: 2).

Berdasarkan alasan di atas, dapat dimaklumi kalau tradisi kajian ilmiah terhadap Islam sulit muncul dari kalangan dalam Islam sendiri, tetapi lebih banyak dikaji oleh kalangan di luar Islam yang memang sudah memiliki tradisi ilmiah. Ada perasaan kurang kurang nyaman bagi seorang muslim atas perlakukan semena-mena terhadap agamanya, sementara bagi orang asing di luar Islam, hal itu tidak menjadi beban sedikitpun. Meskipun begitu, layak diungka teori tentang kebenaran tersebut. AlKindi (796-873 M.), seorang filosof muslim kelahiran Kufah di Irak mengatakan bahwa kebenaran ialah persesuaian antara apa yang ada di dalam akal dengan apa yang ada di luar akal (Nasution, 1975: 16).

Kebenaran yang diberitakan wahyu tidak bertentangan dengan kebenaran yang dibawa filsafat meskipun argumen-argumen Al qur'an lebih meyakinkan dari argumentargumen filsafat, tetapi filsafat dan Al qur'an tidak bertentangan. Jadi, menurut al-Kindi kebenaran ditentukan oleh akal, sementara al-Ghazali berpendapat lain. Menurutnya, kebenaran sejati adalah kebenaran yang dihasilkan dari cahaya intuisi (al-Kasyf) (alGhazali, t.t: 133) karena panca indera sudah tidak dapat lagi dipercaya, begitupun akal (Nasution, 1975: 42). Lebih jauh al-Ghazali memberikan indikasi tentang kebenaran melalui kriteria lima tingkatan wujud. Dalam arti bila satu pernyataan dari seseorang atau satu madzhab kemudian dibatalkan -bahkan, mungkin diklaim "kafir" oleh madzhab lain, maka pernyataan itu masih dianggapsebagai suatu kebenaran bila masih termasuk dalam criteria lima tingkatan wujud tersebut.

Menurut al-Ghazali selanjutnya, pembenaran itu tidak hanya menyentuh pada materi persoalan tetapi juga pada penyampai materi persoalan tersebut. Jadi, siapa pun yang mengakui kebenaran atas apa yang disampaikan Rasulullah melalui lima tingkatan wujud tersebut, maka ia tidak bisa divonis sebagai pembohong agama secara mutlak (al-Ghazali, t.t : 79). Lima tingkatan wujud tersebut adalah sebagai berikut.

Pertama, wujud dzati atau wujud hakiki yaitu wujud yang nyata dalam perasaan dan pikiran seperti wujud bumi, langit, bulan, binatang dan lain-lain.

Kedua, wujud hissi yaitu wujud yang diterima dengan perasaan (indera rasa) dan berada di luar penglihatan mata. Seperti orang tidur dan orang sakit yang menggambarkan mimpinya atau rasa sakitnya, atau gambaran perasaan yang 


\section{A. Zaini Dahlan -- Konsep Makrifat Menurut Al-Ghazali dan Ibnu 'Arabi: Solusi Antisipatif Radikalisme Keagamaan Berbasis Epistemologi}

diterima oleh para nabi dan wali dalam keadaan jaga atau tidur pada sebuah gambar yang indah yang mengekspresikan kasuskasus/materi-materi malaikat yang berakhir dalam bentuk wahyu dan ilham sebagai proses penerimaan masalah-masalah gaib yang juga diterima oleh selain para nabi dan wali dalam tidur mereka berkat kesucian para nabi dan para wali tersebut. Kondisi seperti ini sering dialami Rasulullah tetapi tidak dalam yang asli kecuali pernah dua kali dalam bentuknya yang berbeda juga pernah dialaminya dalam keadaan tidur.

Ketiga, wujud khayali yaitu wujud dalam bentuk gambaran sesuatu yang nyata, setelah sesuatu yang nyata itu hilang dari indera mereka. Jika mata dipejamkan, maka seolaholah gambaran itu disaksikan secara jelas dalam otak padahal kenyataannya tidak ada.

Keempat, wujud akli yaitu wujud yang berawal dari satu pemahaman bahwa pada segala sesuatu terdapat ruh (esensi) realitas (hakikat) dan arti (makna). Kemudian akal menerima arti tunggal wujud tersebut dengan tanpa ada gambarannya secara jelas, baik dalam hayal, pada indera maupun dalam realitas. Contohnya seperti tangan, dia punya bentuk yang bisa diraba dan bisa dihayal oleh otak dan punya makna hakiki yaitu kekuatan untuk menghantam. Kekuatan untuk menghantam inilah yang disebut tangan dalam wujud akli. Kelima, wujud syibhi, yaitu wujud yang selayaknya tidak diwujudkan baik dalam bentuknya, realitas, di luar atau pada indera, dalam hayalan maupun pada akal, tetapi wujud itu berujud dalam bentuk lain yang menyerupai wujud tersebut, baik dalam ciri-cirinya maupun sifat-sifatnya. Contohnya seperti penakwilanpenakwilan (al-Ghazali, 2006: 80).

Meskipun al-Ghazali telah memperkuat golongannya -dimana al-Ghazali termasuk golongan sufi- yang mengungkapkan bahwa kebenaran yang sejati adalah kebenaran yang dihasilkan dari cahaya intuisi yang diperoleh para sufi, namun al-Ghazali masih memberi ruang klaim kebenaran kepada tiga golongan lain pencari kebenaran, yaitu Mutakallimin, Ta'limiyah dan Filosof dengan mengatakan bahwa "kebenaran tidak mungkin berada diluar keempat kelompok ini. Mereka adalah kelompok orang-orang yang menempuh jalan mencari kebenaran. Jika kebenaran tidak bersama mereka, tidak ada jalan lagi yang tersisa dalam usaha mengetahui kebenaran" (Mc Carthy, 1980: 67).

\section{Teori Hermeneutika: Paradigma Tafsir Kontemporer}

Dalam aspek tafsir, Fazlur Rahman dalam buku Islam \& Modernity transformation of an intellectual tradition mengemukakan perlu metode penafsiran Al qur'an yang benar dan baik. Ia mengatakan bahwa $\mathrm{Al}$ qur'an turun bukan dalam ruang kosong, tetapi untuk menjawab dan menyelesaikan masalah-masalah yang muncul ketika itu. Ungkapan ini untuk menegaskan pentingnya memahami konteks dalam memahami Al qur'an.

Kemudian ia mengungkapkan metode hermeneutiknya yang ditawarkan berkaitan dengan cara memahami pesan Al qur'an agar seseorang yang percaya dengan Al qur'an dan ingin menjadikannya sebagai petunjuk dalam kehidupan individu dan kolektif, dapat melakukannya saling berkaitan dan penuh arti. Metode hermeneutiknya sangat sederhana, yaitu membangun gerakan ganda (double movement). Gerakan yang berawal dari memahami situasi sekarang kemudian dibandingkan dengan masa turunnya Al qur'an, lalu kembali lagi ke masa sekarang (Rahman, 1982: 5).

Kemudian Rahman menjelaskan lebih jauh teori double movement-nya, dengan melakukan sebagai berikut. Langkah untuk gerakan pertama adalah (1) memahami makna (content) dengan cara memahami konteks nash. Dalam melakukan hal ini terdiri dari dua langkah, yaitu: memahami makna sebagai satu kesatuan dan menggeneralisasi jawaban khusus; (2) membangun pandangan dari pandangan umum kemudian dibawa ke pandangan khusus untuk diformulasi dan direalisasikan.

Rahman memulai penelitian dengan menulis kritik terhadap karya klasik dan 
pertengahan. Disebutkan bahwa meskipun berabad-abad ada usaha, ilmuwan muslim belum dapat melahirkan metode tafsir yang memuaskan. Kita membutuhkan metode untuk mengambil prinsip kontemporer dari Al qur'an. Metode Qiyas sering menguniversalkan prinsip khusus di atas prinsip umum. Ia memberi alasan kenapa perlu teori dalam interpretasi terhadap Al qur'an yang dan menyebutnya teori hermeneutik.

Pertama, tafsir produk klasik dan pertengahan bersifat parsial dan/atau atomistis, meskipun ada kajian induktif tetapi tidak konsisten. Tafsir macam ini tidak dapat menghasilkan arti yang efektif, yang bersatu dan bermakna bagi kehidupan sebagai keseluruhan.

Kedua, pokok bahasan dalam ilmuilmu $\mathrm{Al}$ qur'an ('Ulum $\mathrm{Al}$ qur'an) juga hanya menekankan pada aspek bahasa, bentuk kata (style), langgam suara (idiom) $\mathrm{Al}$ qur'an, unsur sastra dan makna kiasan. Diakuinya bahwa bahasan ini perlu, tetapi terbatas hanya memahami teks.

Ketiga, karakter Al qur' an sebagai wahyu dan bukan buku biasa yang disusun dan dihubungkan menjadi satu kesatuan yang utuh, tetapi lahir sesuai dengan dan untuk menjawab kebutuhan dan tuntutan. Al qur' an sendiri menyebut status ini dalam QS. al-Furqan (25): 32.

Berdasarkan kekurangan ini, Rahman menawarkan metode hermeneutik yang bertujuan membantu memahami Al qur'an sebagai satu keseluruhan agar menjadi satu keseluruhan yang saling berkaitan, baik unsur teologi maupun etika dan etika-legalnya. Berkaitan dengan pentingnya memahami konteks untuk memahami isi Al qur'an, dan Al qur'an harus dipahami dalam konteksnya, maka Al qur'an harus dipahami secara benar. Memahami Al qur'an dan pentingnya pesan Al qur'an adalah satu pesan. Membatasi pesan $\mathrm{Al}$ qur'an hanya terhadap konteks itu adalah hal lain. Tidak mungkin menguniversalkan pesan $\mathrm{Al}$ qur'an melebihi waktu dan tempat pewahyuan kecuali lewat pemahaman yang benar terhadap artinya.
Ada sejumlah prinsip, baik prinsip agama maupun sosial, tetapi banyak yang bukan prinsip, melainkan hanya sekadar jawaban atau solusi terhadap masalah yang dihadapi Nabi dan masyarakat. Rahman mengibaratkan-hubungan konteks dengan teks Al qur'an sebagai ujung dari gunung es, dimana apa yang tampak yaitu teks Al qur'anhanyalah sebagian kecil saja. Demikian juga ditegaskan fungsi asbab al-nuzul sebagai materi dan mampu untuk memahami aturan hukum yang ada dalam Al qur'an. Diakui bahwa dengan memahami latar belakang sejarah dan memahami konteks Al qur'an dapat membantu memahami arti penting pesan $\mathrm{Al}$ qur'an.

\section{Solusi Antisipatif}

Memahami teks dengan pemahaman secara konstekstual seperti yang dibangun oleh teori resepsi memberi peluang banyak pemahaman-dalam hal ini paham makrifat ittihad Al-Bustami, hulul al-Hallaj, al-kasyf AlGhazali, dan wahdatul wujud Ibnu arabi yang sekaligus memberi pemahaman baru sesuai dengan kondisi kekinian. Dari ajaran ittihad yaitu perasaan menyatunya seorang hamba dengan Tuhannya memberi pelajaran bahwa seharusnya manusia dekat dengan Tuhan dengan melakukan hal-hal yang baik, Tuhan Maha Baik maka yang mendekatiNya pun tentunya yang baik pula.

Sementara ajaran hulul yaitu perasaan bahwa Tuhan bersemayam pada diri hambaNya karena ada persamaan sifatsifat Tuhan (lahut) pada manusia yang mempunyai sifat-sifat Tuhan (nasut) yang memberi pelajaran bahwa sifat-sifat Tuhan sebagai ajaran atau agamaNya yang konsekuensinya agama bersifat plural padahal semua agama-agama itu adalah agama yang satu yaitu agama Tuhan.

Ajaran al-kasyf yaitu terbukannya rahasia-rahasia ketuhanan dan tersingkapnya hukum-hukum Tuhan yang meliputi segala yang ada memberi pelajaran bahwa Tuhan akan senantiasa memberi petunjuk kepada hambaNya ke jalan yang benar yang tentunya kepada mereka (para hamba) 


\section{A. Zaini Dahlan -- Konsep Makrifat Menurut Al-Ghazali dan Ibnu 'Arabi: Solusi Antisipatif Radikalisme Keagamaan Berbasis Epistemologi}

yang mau mengikuti aturanNya. Dari ajaran al-kasyf yang dibangun oleh al Ghazali yang mengatakan bahwa makrifat berarti terbukanya rahasia-rahasia ketuhanan dan tersingkapnya aturan-aturan tuhan yang meliputi segala yang ada memberi pelajaran bahwa orang arif (orang yang bermakrifat) adalah orang-orang yang mengetahui hal-hal yang gaib dan biasa disebut sebagai orang yang mendapat karamah (orang keramat).

Al Ghazali sebagai seorang sufi -dan diduga kuat termasuk orang yang arif sehingga mempunyai karamah- pernah menyatakan bahwa iman yang kokoh ada tiga, yaitu iman kepada Allah, Rasul dan hari akhir. Dan barang siapa beriman kepada ketiga hal tersebut makan haram darahnya, dalam arti ia tidak boleh dibunuh dan dihormati hak-hak sipilnya. (al Ghazali, tt : 89). Pendapat al-Ghazali di atas dapat membangun kesatuan visi bahwa umat beragama -dengan keimanan yang sama, paling tidak dalam tiga unsur iman di atassudah selayaknya membangun toleransi, saling menghargai terlebih lagi menghindari tindakan radikalisme.

Dan dari ajaran wahdatul wujud yaitu pandangan bahwa alam semesta ini adalah hakikat diri Tuhan memberi pelajaran bahwa manusia itu adalah satuan makhluk Tuhan -umat manusia itu adalah umat yang satuyaitu umat yang menyembah kepada satu tuhan yaitu Allah. Ide ini identik dengan ajaran ekumenisme (berasal dari bahasa yunani oiukemene) yang berarti tanah yang didiami (Abdallah, $2010: 7$ ).

\section{SIMPULAN}

Dengan menggunakan teori resepsi, dari teks dihasilkan beberapa paham atau ajaran dalam tasawuf, yaitu makrifat al kasyf (al Ghazali), ittihad (Abu Yazid al Busthami) hulul (al Hallaj) dan Wahdatul Wujud (Ibnu Arabi). Teori resepsi adalah teori sastra yang dianggap kontemporer. Sebaliknya, bila menggunakan teori penafsiran klasik, maka lebih cenderung akan mempertahankan bahkan memperkuat trdisi heresiograpi yang berakibat dan memicu timbulnya konflik teologis.
Pada masing-masing aliran atau komunitas suatu golongan ada persamaanpersamaan paham disamping ada perbedaan diantara mereka. Pada tataran kesamaan paham dalam "nodes", sebagai indikasi nilai universal, dijadikan basis untuk membangun kesatuan umat. Sementara pada tataran "perbedaan", dibangun paradigma teologis dan psikologis yaitu satu kesadaran bahwa kebenaran bersifat pluralis yang merefleksikan masing-masing aliran bersikap saling menghargai dan menghormati terhadap sesamanya.

Melalui pendekatan tafsir klasik, ajaran makrifat dipahami sebagai terbukanya rahasi-rahasia ketuhanan dan tersingkapnya hukum-hukum Tuhan yang meliputi segala yang ada. Ajaran ini diungkap oleh para sufi aliran Sunni. Sementara melalui pendekatan tafsir kontemporer, ajaran makrifat dipahami sebagai al Ittihad, al Hulul dan Wahdatul Wujud. Dan paham ini didukung oleh para sufi aliran falsafi. Dalam penafsiran kontemporer pula dihasilkan tesis: kebenaran bersifat plural nilai-nilai universal merupakan perioritas utama dan kemaslahatan adalah satu niscaya. Dengan demikian menghormati pendapat orang lain, bersikap adil serta membangun kemaslahatan bersama harus dilakukan dalam rangka antisipasi radikalisme.

\section{DAFTAR PUSTAKA}

Ali, A.t.t., Kamus Krapyak al 'Asri, Yogyakarta: Multi Karya Grafika.

Al-Ghazali, A, 1980. Ihya Ulum al-Din, Jilid I, II, III dan IV Semarang: Toha Putera. 2006, Faishal al-Tafriqah. Libanon: Dar al-Kutub al-Ilmiyah, 1961, Al-Munqidz min al-Dhalal, Kairo: Silsilah al-Tsaqafah.

Al-Qusyairi, 1966, Risalah Al-Qusyairiyah, Kairo: Muhammad Ali Shabih wa Awladih.

Afifi, A.A., 2009, Al-Falsafah al-Sufiyah 'ind Ibn 'Arabi, Kairo: Dar al-Kutub wa alWatsaiq al-Qaumiyah. 
Azhari, K, 1995, Ibn al-'Arabi: Wahdat al-Wujud dalam Perdebatan, Jakarta: Paramadina.

Azra, A, 2004, Jaringan Ulama Timur Tengah dan Kepulauan Nusantara Abad XVII dan XVIII, Jakarta : Prenada Media.

Bakar, O, 1998, Hierarki Ilmu, Membangun Rangka Pikir Islamisasi Ilmu, Bandung: Mizan.

Bukhari, M.I., Al-Shahih Al-Bukhari, t.t, Dar Al-Mathabi' Al-Sya'b.

Carthy, Mc, 1980, Freedom and Fulfillmant: Annotated Translation of Al Munqidz Min Al Dhalal and Other Relevant works of al-Ghazali, Terjemahan RJ. McCarthy, Boston.

Departemen Pendidikan dan Kebudayaan Republik Indonesia, 1993, Pedoman Umum Ejaan Bahasa Indonesia Yang Disempurnakan, Bandung: PT. Gramedia Widiasarana Indonesia.

Echols, J.M., dan Hassan S, 1979, Kamus Inggris-Indonesia, Cetakan ke-4, Jakarta: Gramedia.

Fokkema, D.W. dan Elrud Kunne-Ibrsch, 1977, Theories of Literature in The Twentieth Centuries, London: C. Hurst \& Company.

Ibnu Arabi, t.t, Al-Futuhat al-Makkiyah, Jilid II, Beirut: Dar Shadir.

, Tafsir Ibn 'Arabi, 2002, Cetakan 1, Beirut: Dar Shadir.

, t.t, Fushush al-Hikam wa al-Ta'liqat Alaih, Abu al-'Ala Afifi (Ed.), Beirut: Dar al-Fikr.

Iser, W, 1978, The Act of Reading: A Theory of Aesthetic Respons, London: The John Hopkins Press.

Jamil, H.M., 2007, Cakrawala Tasawuf: Sejarah Pemikiran dan Kontekstualitas, Jakarta: Gaung Persada Press.

Al-Jaelani, A. Q., 2009, Cet.2, Tafsir al-Jaelani, Beirut: Syarikat at-Tamam.

Jauss, H.R., 1982, Toward in Aesthetic of Receptions, Minneapolis: University of Minnesota Press.
Al-Jili, A,t.t, Al-Insan al-Kamil fi Ma'rifat alAwakhirwa al-Awail, Kairo: Maktabah Zahran.

Khaldun, I, 2006. Muqaddimah Ibn Khaldun. Terjamahan dari Muqoddimah ibn Khaldun. Jakarta: Gema Insani Press.

Mitsa, F, 2005, Al-Ghazali wa al-Ismailiyun: al-'Aql wa Sulthah fi Islam al-Ashr alWasith, Beirut: Dar al-Saqi.

Mahasin, 2003, "Sesungguhnya ada Shared Truth" dalam Relief: Journal of Religious Issues forum I, No. 2, Yogyakarta: CRCS UGM.

Nasution, H, 1973, Falsafat dan Mistisisme dalam Islam, Jakarta: Bulan Bintang. 1984, Islam Ditinjau dari Berbagai Aspeknya, Jakarta: UI-Press.

1986, Teolog: Islam Aliran-aliran Sejarah dan Analisa Perbandingan, Jakarta: UIPress.

Nasution, Y, 1988, Manusia Menurut AlGhazali, Jakarta: Rajawali Pers.

Pradopo, R.D., 1990, Pengkajian Puisi, Yogyakarta: Gajah Mada University Press.

Saliba, J, 1979, Mu'jam al-Falsafi, Jilid III, Beirut: Dar al-Kitab.

Sangidu, 2003, Wachdatul Wujud: Polemik Pemikiran Sufistik antara Hamzah Fansuri dan Syamsudin As-Samatrani dengan Nurudin Ar-Raniry, Yogyakarta: Gama Media.

Tim YPPA, 1994, Al-Qur'an dan Terjamahnya Jakarta: Jakarta: Yayasan Penyelenggara Penterjemah AlQur'an Departemen Agama.

Wahid, M, 2005, Islam dan Pluralisme: Anganangan Sosial Politik Demokratif Piagam Madinah dalam Nilai-Nilai Pluralisme dalam Islam, dalam Jurnal Lektur Seri XVII, Cirebon: STAIN.

Watt, W.M., 1972, The Formatif Period of Islamic Thougth, Edinburg: Edinburg University Press. 